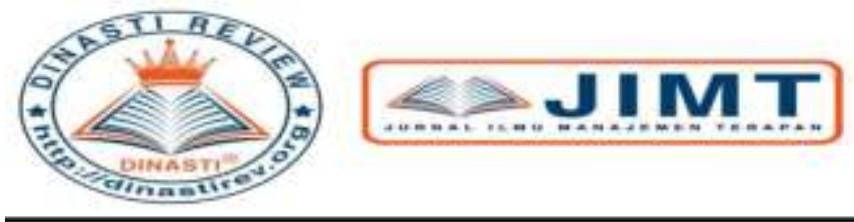

+62 878-9658-6407

087896586407

https://dinastirev.org/JIMT editor@dinastirev.org

\title{
STRATEGI PEMASARAN PRODUK SOSIS SIAP MAKAN (STUDI KASUS: PT Z)
}

\section{Eko Supriyanto}

Universitas Mercu Buana, Jakarta, Indonesia

ARTICLE INFORMATION

Received: 02/11/2019

Revised: $11 / 11 / 2019$

Issued: $20 / 11 / 2019$

(filled in by Editor)

Corresponding Author: First author

E-mail:

ekosupriyanto@gmail.com

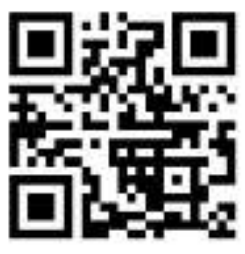

DOI:10.31933/JIMT
Abstrak: Masalah yang dihadapkan produk cepat makan berupa sosis daging dan ayam dari PT Z dengan merek X adalah kalah besaing dengan pesaing dipasar serta penjualan yang cenderung fluktuatif sepanjang tahun. Penelitian ini dilakukan dengan tujuan yang dirumuskan dari uraian latar belakang. Penelitian ini bertujuan untuk (1) Mengidentifikasi faktor-faktor internal dan eksternal perusahaan dalam pemasaran produk sosis siap makan merek X tersebut, (2) Memformulasikan strategi yang dapat dilakukan oleh perusahaan untuk meningkatkan pemasaran sosis siap makan pada pasar yang menyangkut produk, harga, promosi dan distribusi, (3) Merekomendasikan strategi terbaik dari beragam alternatif strategi yang dapat dirumuskan. Metode analisis yang digunakan adalah analisis SWOT. Hasil dari penelitian ini adalah Rumusan alternatif strategi pemasaran yang didapatkan berdasarkan faktor-faktor eksternal dan internal adalah bekerjasama dengan partner, diferensiasi produk, promosi gabungan dengan grup $\mathrm{Y}$, serta promosi edukatif. Berdasarkan hasil SWOT-ANP didapatkan bahwa promosi edukasi merupakan prioritas strategi utama yang direkomendasikan.

Kata Kunci: Pemasaran, Swot-Anp, Sosis Siap Makan

\section{PENDAHULUAN}

Pangan merupakan salah satu kebutuhan dasar manusia untuk menunjang kehidupannya. Kebutuhan akan pangan meningkat seiring dengan meningkatnya pertumbuhan penduduk. Penduduk Indonesia yang diperkirakan akan terus meningkat, dimana pada tahun 2010 penduduk Indonesia berjumlah 230.8 juta jiwa dan diprediksi meningkat pada tahun 2035 menjadi 305.6 juta jiwa. Pemilihan pangan yang dilakukan oleh masyarakat sebaiknya memperhatikan kandungan gizi yang terdapat dalam makanan tersebut, salah satunya adalah protein. Konsumsi protein masyarakat Indonesia sejumlah 55 gram/kap/hari. Pemenuhan zat gizi protein pada masyarakat umumnya berasal dari produk hewani maupun nabati. Produk hewani berupa daging merupakan salah satu sumber protein yang umum dikonsumsi oleh masyarakat Indonesia. Daging ayam olahan 2 merupakan pangan hewani yang paling banyak dikonsumsi oleh masyarakat Indonesia 
untuk dapat memenuhi kebutuhan proteinnya, dan diikuti oleh protein hewani lainnya seperti daging sapi dan daging kambing. Konsumsi perkapita daging ayam dan daging sapi dari tahun ke tahun cenderung meningkat dibandingkan oleh konsumsi daging lainnya. Harga daging ayam yang cukup terjangkau dan jumlah yang cukup banyak di pasaran membuat daging ayam cukup banyak dipilih masyarakat untuk memenuhi kebutuhan sumber protein hewaninya dibandingkan daging hewan lainnya karena harganya yang relatif terjangkau. Pertumbuhan konsumsi produk hewani masyarakat menarik minat produsen pangan untuk membuat daging ayam maupun sapi olahan yang cepat dan siap makan, salah satunya adalah PT Z yang melihat ini sebagai peluang bisnis dengan memproduksi sosis siap makan dengan merek X. Berdasarkan hasil survei yang dilakukan oleh Group W dalam penganugerahan "Top Brand Award", produk sosis dari Z dengan merek X berada pada posisi dua dengan persentase sebesar 27\%. Merek tersebut kalah besaing dengan kompetitor, yaitu merek A. Pangsa pasar dari daging olahan di Indonesia ditampilkan pada Gambar 1 dibawah ini.

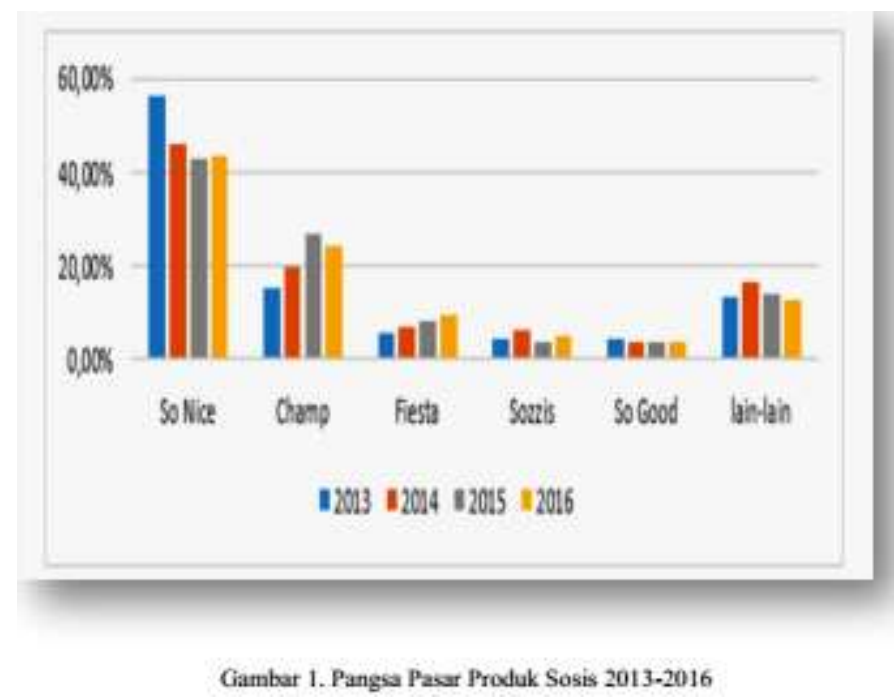

\section{METODE PENELITIAN}

Sumber data yang digunakan dalam penelitian ini berupa data primer dan data sekunder. Data primer diperoleh dengan melakukan survei menggunakan kuesioner, wawancara yang mendalam dengan berbagai narasumber dari pihak PT Z serta observasi. Kuesioner yang digunakan merupakan kuesioner semi terstruktur yang pengisiannya dipandu oleh peneliti. Wawancara mendalam dilakukan secara langsung dengan responden yang dipilih berdasarkan pertimbangan bahwa responden merupakan seseorang yang ahli dan kompeten pada bidangnya, seperti manajer dan direktur.

\section{HASIL DAN PEMBAHASAN}

\section{Produk}

Produk sosis siap makan $\mathrm{X}$ merupakan produk yang terbuat dari daging ayam dan sapi pilihan. Produk sosis siap makan merek X telah melalui pengawasan quality control (QC) yang ketat dengan memerhatikan standar sistem ISO 9001:2008, HACCP dan FSSC yang telah diterapkan dalam produksi dan pengolahan sosis siap makan pada PT Z tersebut. Produk sosis siap makan X ini juga telah mendapatkan sertifikasi Halal dari Majelis Ulama Indonesia serta sertifikasi dari Badan Pusat Obat dan Makanan (BPOM) yang menjamin bahwa 
produknya aman untuk dikonsumsi. Saat ini sosis siap makan X memiliki empat varian rasa yang terdiri dari rasa ayam original, sapi original, daging sapi rasa rendang dan daging ayam rasa keju. Semua produk siap makan $\mathrm{X}$ diolah dengan menggunakan bumbu-bumbu pilihan. Produk sosis siap makan $\mathrm{X}$ dijual dalam toples, dimana dalam satu toples terdiri dari 30 buah sosis siap makan dengan berat masingmasing sebesar 16 gram.

\section{Harga}

Produk sosis siap makan X dipasarkan dalam toples dengan isi masing-masing toples terdiri dari 30 buah sosis siap makan. Produk sosis siap makan X dijual dan dapat dibeli dalam satuan toples atau satuan kardus, dimana satu kardus berisi enam toples. Penentuan harga jual sendiri dilakukan oleh perusahaan. Harga jual yang ditetapkan oleh perusahaan sebesar Rp97.000 per dus. Perusahaan juga menetapkan harga jual keuntungan sebesar 11\% untuk harga jual di bawah. Berdasarkan hasil penelitian diketahui bahwa harga jual eceran untuk satu toples dijual dengan harga antara Rp24.000 hingga Rp30.000 per toples.

\section{Promosi}

Promosi adalah kegiatan penjualan dan pemasaran dalam rangka menginformasikan, memperkenalkan dan mendorong permintaan terhadap produk, jasa, dan ide - ide dari perusahaan dengan cara mempengaruhi konsumen agar membeli produk dan jasa yang dihasilkan oleh perusahaan (Rangkuti, 2009). Selama ini, PT Z juga mempromosikan produk sosis siap makan $\mathrm{X}$ melalui beberapa cara antara lain:

a. Internet. Produk sosis siap makan $\mathrm{X}$ memiliki media promosi melalui media sosial Facebook yang dapat diakses oleh masyarakat.

b. Mengadakan pameran atau event di berbagai sekolah dasar di seluruh Indonesia dengan menawarkan contoh produk secara gratis kepada para siswa

c. Memberikan hadiah berupa kartu permainan yang diberikan apabila membeli produk sosis siap makan X.

d. Mengadakan pameran atau event yang dilaksanakan di beberapa tempat seperti kegiatan car free day dan Jakarta fair

e. Membagikan poster dengan sasaran kantin-kantin sekolah, warung, toko, grosir dan sebagainya.Membuat iklan yang ditayangkan di televisi untuk produk sosis siap makan X.

\section{Distribusi}

Peningkatan proses penjualan produk ditentukan oleh banyak hal, salah satunya adalah saluran distribusi. Saluran distribusi yang dikelola dengan baik dan optimal akan memudahkan konsumen untuk memperoleh produk tersebut. PT Z juga sangat memerhatikan masalah tersebut. PT Z merupakan perusahaan perdagangan makanan olahan yang menjual produk-produk hasil olahan dari PT Y Indonesia, salah satu produk yang dijual adalah sosis siap makan dengan merek X. PT Z bertindak sebagai principle dari produk sosis siap makan merek X. Perusahaan principle merupakan pemilik dari produk yang didistribusikan oleh distributor. Sebagai principle, PT Z juga bekerjasama dengan pihak ketiga yang bertindak sebagai distributor barang untuk memasarkan sosis siap makan X. Produk sosis siap makan X telah dipasarkan ke berbagai supermarket, minimarket, grosir, warung yang ada di seluruh Indonesia. Distribusi yang baik akan memberikan hasil terhadap produk yang dipasarkan sehingga produk mudah diakses oleh konsumen. Berdasarkan penelitian Novita et al. (2014) 
dan Utomo et al. (2011) mengungkapkan bahwa konsumen menginginkan produk yang mudah dijangkau dari tempat tinggal konsumen.

\section{Identifikasi Faktor Internal dan Faktor Eksternal}

Berdasarkan hasil penelitian, dapat diidentifikasikan faktor-faktor internal dan eksternal PT Z.

\section{Kekuatan}

a. Bahan baku berkualitas Lupiyoadi (2001) menjelaskan bahwa kualitas adalah keseluruhan ciri-ciri dan karakteristikkarakteristik dari suatu produk/jasa dalam hal kemampuan untuk memenuhi kebutuhan-kebutuhan yang telah ditentukan/bersifat laten. Produk sosis siap makan merek $\mathrm{X}$ menggunakan bahan-bahan yang berkualitas. Produk sosis siap makan X menggunakan daging ayam sebesar 37,5\% dan daging sapi sebesar $18 \%$. Semua produk sosis siap makan merek $\mathrm{X}$ telah mendapatkan sertifikasi produk sesuai dengan ISO 9001 : 2008. Produk sosis siap makan $\mathrm{X}$ menggunakan bahan-bahan yang aman dan telah tersertifikasi oleh BPOM.

b. Harga produk yang terjangkau. Beberapa faktor berpengaruh dalam pembelian produk oleh konsumen. Salah satu faktor yang memengaruhi pembelian produk adalah harga (Albari \& Liriswati, 2004; Meilani \& Simanjuntak 2012). Produk sosis siap makan X memiliki harga produk yang terjangkau. Berdasarkan hasil penelitian diketahui bahwa produk sosis siap makan $\mathrm{X}$ dijual dengan harga Rp15.000 sampai Rp25.000 per toples. Harga ini masih cukup terjangkau bagi konsumen. Harga ini juga termasuk murah apabila dibandingkan kompetitor.

c. Integrasi dengan Y Grup PT Z, selaku principle dari sosis siap makan merek X, merupakan bagian dari Y Grup. Berbagai 7 lini bisnis yang dimiliki oleh Y dan dapat dimanfaatkan untuk meningkatkan penjualan sosis siap makan X. Salah satu lini bisnis yang dimiliki Y Indonesia yang dapat meningkatkan penjualan sosis siap makan merek X adalah kepemilikan Y Indonesia atas toko waralaba dengan merek "Prima Fresh Mart". Toko waralaba Prima Fresh Mart telah tersebar di berbagai daerah di Indonesia. Toko waralaba Prima Fresh Mart menjual segala macam produk yang dihasilkan oleh Y Grup dipasarkan secara ekslusif. Banyaknya jumlah Prima Fresh Mart yang ada memudahkan konsumen untuk mengakses produk-produk olahan dari Y Grup, termasuk sosis siap makan X. Semakin banyak dan berkembangnya toko waralaba yang tergabung dalam $Y$ Grup diharapkan dapat meningkatkan penjualan produk sosis siap makan X.

d. Brand image produk yang baik Produk sosis siap makan $\mathrm{X}$ memiliki komponen atribut produk yang baik dimana sosis siap makan $\mathrm{X}$ merupakan produk yang terbuat dari daging terbaik, rasa yang enak serta harga yang terjangkau. Selain itu, produk sosis siap makan $\mathrm{X}$ juga memiliki keuntungan bagi konsumen berupa sumber protein hewani yang mudah dikonsumsi tanpa harus diolah terlebih dahulu. Beberapa komponen tersebut membentuk merek X menjadi brand image yang baik.

\section{Kelemahan}

a. Produk yang rentan rusak

Produk sosis siap makan $\mathrm{X}$ merupakan sosis siap makan yang dipasarkan dalam bentuk toples dan terdiri dari 30 buah dalam setiap toples. Produk sosis siap makan $\mathrm{X}$ dibungkus menggunakan plastik yang telah diikat dengan menggunakan pengaman. Produk sosis siap makan $\mathrm{X}$ terbuat dari bahan baku daging yang memiliki masa berlaku produk yang tidak lama. Hal ini berpengaruh terhadap proses penyimpanan dan penjualan dari produk tersebut. Penyimpanan yang kurang baik dari produk akan berdampak pada ketahanan produk sehingga dapat menyebabkan rusak.

Masalah yang ditemukan saat penelitian yang menyebabkan produk mudah rusak antara lain penyimpanan produk yang kurang baik. Sosis siap makan merek X Proses penyimpanan 
dan penjualan yang terkadang terkena matahari mengakibatkan bakteri masuk kedalam produk yang berbahan dasar daging sehingga membuat produk tidak layak dijual. Selain itu, toples tempat penyimpanan yang mudah rusak saat penyimpanan mengakibatkan produk mudah rusak hingga tidak layak jual.

b. SDM pemasaran yang kurang

SDM merupakan sumber keunggulan kompetitif yang paling sulit ditiru dan bertahan lebih lama (Handoko, 2002 dalam Ferrinadewi, 2004). Terbatasnya sumber daya manusia dalam perusahaan membuat pemasaran produk kurang optimal.

SDM dalam pemasaran yang dimiliki PT Z masih kurang. Berdasarkan hasil penelitia diketahui bahwa setiap supervisor hanya dibantu sekitar 2 hingga 3 motoris untuk menangani daerah penjualan masing-masing. Hasil dari wawancara tersebut menyebutkan bahwa setidaknya dibutuhkan 4 sampai 5 untuk menangani daerah penjualan masing-masing. Akibat dari kekurangan sumberdaya manusia tersebut penjualan produk belum maksimal karena kurangnya jangkauan wilayah yang dicapai.

\section{Analisis Matriks SWOT}

Matriks SWOT digunakan untuk merumuskan alternatif strategi pemasaran yang dapat diterapkan di PT Z. Matriks SWOT dapat menggambarkan peluang dan ancaman eksternal yang dihadapi usaha pemasaran sosis siap makan $\mathrm{X}$ dapat disesuaikan dengan kekuatan dan kelemahan internal. Matriks ini menghasilkan empat sel kemungkinan alternatif strategi, yaitu strategi S- O, strategi W-O, strategi S-T dan strategi W-T seperti disajikan pada Gambar 2.

\section{Analytic Network Process}

Berdasarkan matriks SWOT didapatkan alternatif strategi untuk peningkatan penjualan sosis siap makan $\mathrm{X}$. Tahap selanjutnya adalah pemilihan prioritas pemilihan strategi untuk peningkatan penjualan sosis siap makan $\mathrm{X}$ menggunakan teknik Analytic Network Process (ANP). Penentuan prioritas strategi merupakan gabungan dari 3 responden ekternal dan internal. Kerangka yang digunakan dalam metode ANP ditampilkan dalam Gambar 3.

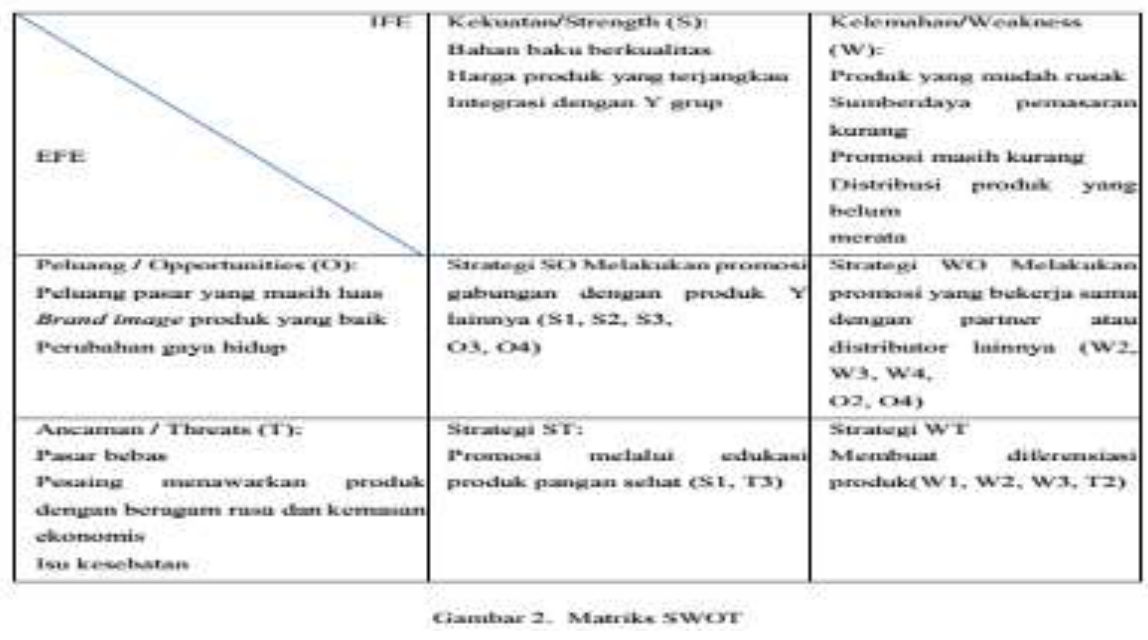




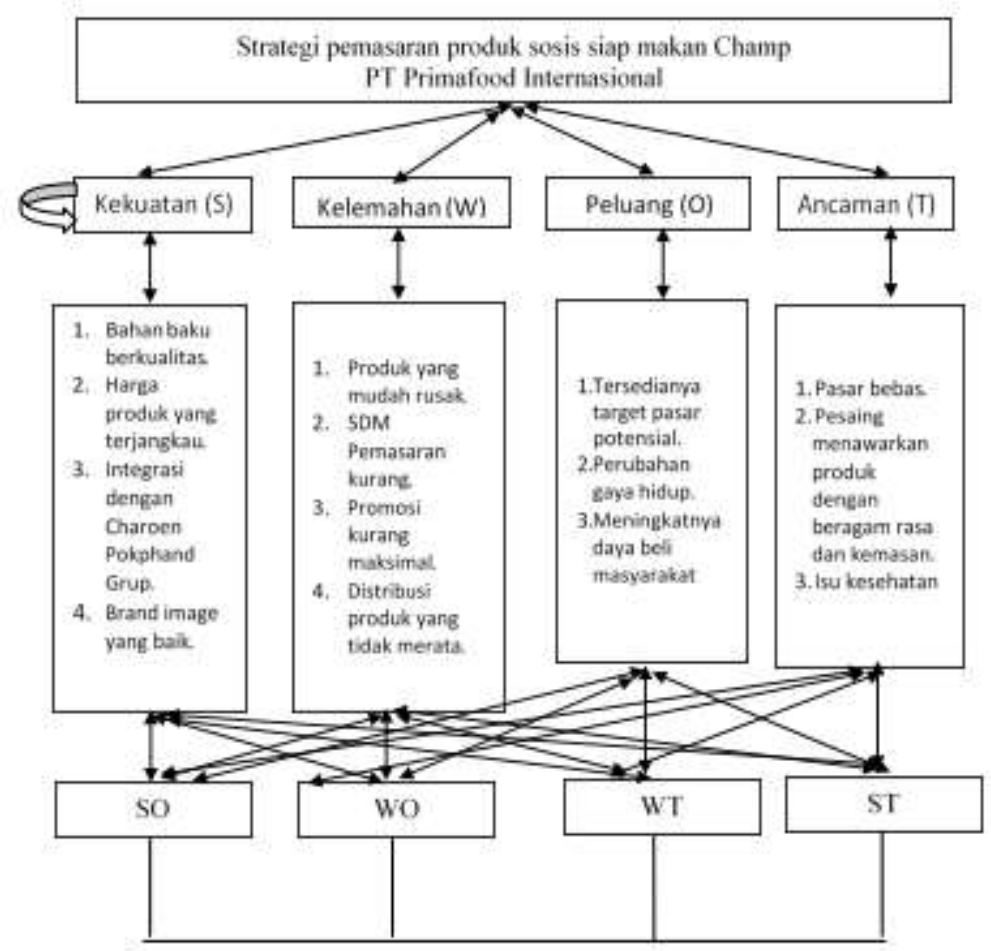

Gambar 3. Kerangka ANP strategi peningkatan penjualan sosis siap makan

\section{KESIMPULAN}

PT Berdasarkan penelitian pemilihan strategi untuk meningkatkan penjualan sosis siap makan X diketahui bahwa terdapat faktor internal dan eksternal yang memengaruhi penjualan produk sosis siap makan X. Untuk faktor internal terdapat beberapa hal yaitu kekuatan dan kelemahan. Dimana bahan baku yang berkualitas, brand image yang baik, harga yang terjangkau, serta intergrasi dengan grup merupakan kekuatan yang dimiliki. Untuk distribusi yang kurang merata, produk yang rentan rusak, promosi yang kurang maksimal, serta sumber daya pemasaran yang kurang merupakan kekurangan yang dimiliki oleh perusahaan. Selain itu, terdapat faktor eksternal yang menjadi perhatian perusahaan yaitu peluang dan ancaman. Untuk peluang yang dimiliki perusahaan adalah daya beli meningkat, pasar potensial serta perubahan gaya hidup. Namun demikian, terdapat beberapa hal yang menjadi ancaman perusahaan yaitu isu kesehatan, pasar bebas, produk pesaing. Rumusan alternatif strategi yang didapatkan berdasarkan faktor-faktor eksternal dan internal adalah bekerjasama dengan partner, diferensiasi produk, promosi gabungan dengan grup $\mathrm{Y}$, serta promosi edukatif. Berdasarkan perhitugan metode ANP, strategi promosi edukatif merupakan strategi dengan prioritas tertinggi dengan nilai normal sebesar 0,279334 .

\section{DAFTAR RUJUKAN}

Albari \& Liriswati. 2004. Analisis Minat Beli Konsumen Sabun Cair Lux, Biore dan Lifebuoy di Kotamadya Yogyakarta Ditinjau dari Pengaruh Sikapnya Setelah Melihat Iklan di Televisi dan Norma Subyektif. Jurnal Siasat Bisnis, 2(9).

Ali, W., \& Listiyorini. (2013). Pengaruh Keragaman Menu, Kualitas Produk, Citra Merek dan Iklan terhadap Keputusan Pembelian. Diponegoro Journal of Social and Politic , 1-9. 
Azis, I.J., L.M. Napitupulu, A.A. Patunru, B.P. Resosudarmo. 2010. Pembangunan Berkelanjutan; Peran dan Kontribusi Emil Salim. Jakarta (ID): PT Gramedia.

Belangkaege, R., D. Engka, D. Mandeij. 2014. Analisis Struktur Pasar, Perilaku, dan Kinerja Industri Perbankan Indonesia (Studi Pada Bank yang Terdaftar di BEI periode 20082012). Jurnal Berkala Ilmiah Efisiensi. 14(3): 43-55

Ferrinadewi, E. 2004. Upaya Mencapai Loyalitas Konsumen dalam Perspektif Sumber Daya Manusia. Jurnal Manajemen \& Kewirausaha- an. 6(1): 15-26

Ismajli, A., S. Kajtazi, E. Fejza. 2013. The impact of promotional activities on purchase decision making: A case study of brands bonita and rugove-water bottled producers. European Scientific Journal. 9(31): 465-474. ISSN: 1857-7431.

Lupiyoadi, R. 2001. Manajemen Pemasaran Jasa. Jakarta (ID): PT. Salemba Empat. 